\title{
Detection of maternal cell contamination in amniotic fluid cell cultures using fluorescent labelled microsatellites
}

\author{
Geoffrey W Smith, Colin A Graham, Jean Nevin, Norman C Nevin
}

\begin{abstract}
A rapid PCR based assay was used to ascertain the presence of maternal cell contamination (MCC) in amniotic fluid cell cultures and to exclude MCC in cases where cytogenetic analysis was possible only from one primary cell culture. Six 6-carboxyfluorescein (FAM) and three 6carboxyfluorescein hexachloride (HEX) labelled primer sets were used to amplify two tetra- and seven dinucleotide repeat polymorphisms. The PCR amplifications were multiplexed in (three) three primer set reactions and visualised on an Applied Biosystems 373A sequencer running Genescan 672 software. The microsatellite products obtained from 200 amniotic fluid cell cultures where the karyotype was female were compared against corresponding maternal blood PCR products. A single case of MCC was detected indicating the usefulness of such assays. We suggest that screening for MCC should be considered in instances where the amniotic fluid sample is bloodstained or was obtained with difficulty, or where the karyotype is female and chromosome analysis is not possible from more than one primary cell culture.
\end{abstract}

(f Med Genet 1995;32:61-64)

Microsatellites are highly polymorphic DNA markers which display a variable number of easily identifiable alleles based on very short (2-4 bp) tandem repeats. ${ }^{1-5}$ These markers occur every 300 to $500 \mathrm{~kb}$ on the human X chromosome and appear to be dispersed at this frequency (an estimated 400 million loci in total) throughout the genome. ${ }^{67}$ Their abundance has revolutionised the construction of high resolution linkage maps for each chromosome, which may be used to map disease and nondisease genes. ${ }^{8-10}$ In addition microsatellites also offer unlimited potential for highly discriminatory tests for human identification and their use in the field of forensic science and for paternity testing is well documented. ${ }^{11-14}$ The explosion in microsatellite applications has been rapidly followed by the development of fluorescence based systems for the semiautomated analysis of PCR generated DNA fragments. ${ }^{15}$ These systems offer numerous advantages over conventional methods including automated real time analysis as the alleles pass a detection window, coupled with the ability to run hundreds of samples on a single gel multiplexed either by coamplification or by coelectrophoresis based on dye colour or PCR product length. Furthermore, the use of an internal lane standard allows accurate allele sizing and quantitation, so removing the problem of band shift artefacts and between gel variation often encountered with other techniques. In addition the need for radioisotopes and time consuming postelectrophoresis handling steps (such as blotting/autoradiography and silver staining) are eliminated. Here we describe the application of fluorescent microsatellite analysis to the problem of maternal cell contamination in amniotic fluid cell cultures.

The majority of errors in the cytogenetic analysis of cultured amniotic fluid cells are the result of contamination of the cultures with cells of maternal origin. This poses a serious potential source of prenatal misdiagnosis and there have been at least four documented cases of aneuploidy being missed. ${ }^{16}$ The data from four large collaborative surveys suggest a mean MCC frequency of $0 \cdot 25 \% .{ }^{17-20}$ However, as the criterion for assigning MCC was the admixture of male and female cells, the true frequency allowing for undetected cases (where the fetal karyotype was female) is likely to be approximately twice the observed figure. Benn and $\mathrm{Hsu}^{17}$ showed considerable variability among individual laboratories. For institutions reporting more than 1000 amniocenteses, observed frequencies varied from $0 \%$ to $0.543 \%$. As previously indicated these values are approximately half the true incidences owing to non-recognition of MCC when the fetal karyotype is female. In addition, the proportion of maternal cells was shown to be highly variable, consisting of a single XX cell in $25 \%$ of cases, multiple XX cells restricted to a single flask in $53.8 \%$ of cases, and $21.2 \%$ of cases which showed multiple XX cells in two or more primary cultures. This observation led to the proposal that cytogenetic analysis should be performed on a minimum of 20 metaphases from two or more independent primary cultures. Nevertheless the potential for error remains for the prenatal diagnosis of biochemical or genetic disorders (such as leucodystrophy and cystic fibrosis), where the properties of an entire cell population are determined. In this paper we describe the semiautomated detection of three fluorescent triplex PCR systems: D8S88 coamplifying with FXIII and vWF; D7S528 coamplifying with D1S250 and 
Table 1 Characteristics and primer sequences of the microsatellite loci used to screen for cases of suspected MCC in amniotic fluid cell cultures

\begin{tabular}{|c|c|c|c|c|c|c|}
\hline Locus & $\begin{array}{l}\text { Chromosome } \\
\text { location }\end{array}$ & $\begin{array}{l}\text { No of } \\
\text { alleles* }\end{array}$ & $\begin{array}{l}\text { Size } \\
\text { range }(b p)\end{array}$ & $P I C$ & $P C R$ primers $\left(5^{\prime}-3^{\prime}\right)$ & Fluorophore \\
\hline FXIII & $6 \mathrm{p} 24-\mathrm{p} 25$ & 9 & $180-230$ & $0 \cdot 68$ & \multirow{9}{*}{$\begin{array}{l}\text { GAGGTTGCACTCCAGCCTTT } \\
\text { ATGCCATGCAGATTAGAAA } \\
\text { TCCTTCCATGTACTCTGCA } \\
\text { TGCCCTGAAGCACATGTGT } \\
\text { TGTACCTAGTTTCTATCCTG } \\
\text { GTGATGATGATGGAGACAGAG } \\
\text { AAAAACGTACTGCCACATTC } \\
\text { ACTTGTAGGCCTGTTCTGAG } \\
\text { CATAGCGAGACTCCATCTCC } \\
\text { GGGAGAGGGCAAAGATCGAT } \\
\text { TCAACTTGATTTCACTTTCAG } \\
\text { CATGTGCGTGCTTGTGT } \\
\text { AGCTAGATTTTACTTCTCTG } \\
\text { CTGGTTGTACATGCCTGAC } \\
\text { GAAATCTCAAAAGACAAACAAGT } \\
\text { GATCGTTCTTGCTGATTTT } \\
\text { TTCAGCAGAGAAAGGGTTAT } \\
\text { GGCAAAGAGAACTCATCAGA }\end{array}$} & 6-FAM \\
\hline D21S167 & $21 \mathrm{q} 22.2$ & 11 & $153-175$ & $0 \cdot 7$ & & HEX \\
\hline vWF & 12p12-pter & 7 & $155-179$ & $0 \cdot 7$ & & 6-FAM \\
\hline D1S250 & $1 \mathrm{p} 13$ & 8 & $132-148$ & $0 \cdot 81$ & & HEX \\
\hline APOC2 & $19 \mathrm{q} 13.2$ & 14 & $127-163$ & 0.82 & & 6-FAM \\
\hline D7S528 & $7 \mathrm{p} 15$ & 5 & $108-116$ & 0.67 & & HEX \\
\hline D18S35 & $18 \mathrm{q} 21.2$ & 9 & $104-124$ & $0 \cdot 73$ & & 6-FAM \\
\hline D10S109 & 10q11.2-qter & 8 & $82-96$ & $0 \cdot 71$ & & 6-FAM \\
\hline D8S88 & $8 q 22$ & 10 & 81-99 & $0 \cdot 77$ & & 6-FAM \\
\hline
\end{tabular}

* Allele frequency distribution for each marker is available on request from the author.

D21S167; and D10S109 coamplifying with D18S35 and APOC2. PCR products at these loci were then used to determine the level of MCC and as a rapid assay to exclude MCC in cases where only one primary cell culture has been successfully established and where the karyotype is female.

\section{Materials and methods}

AMNIOTIC FLUID CELL CULTURES AND DNA EXTRACTION

Amniotic fluid cell cultures were established in $25 \mathrm{~cm}^{2}$ flasks in accordance with routine methods. ${ }^{21}$ The flask cells were washed with PBS and DNA was extracted by ethanol precipitation following guanidine and protease

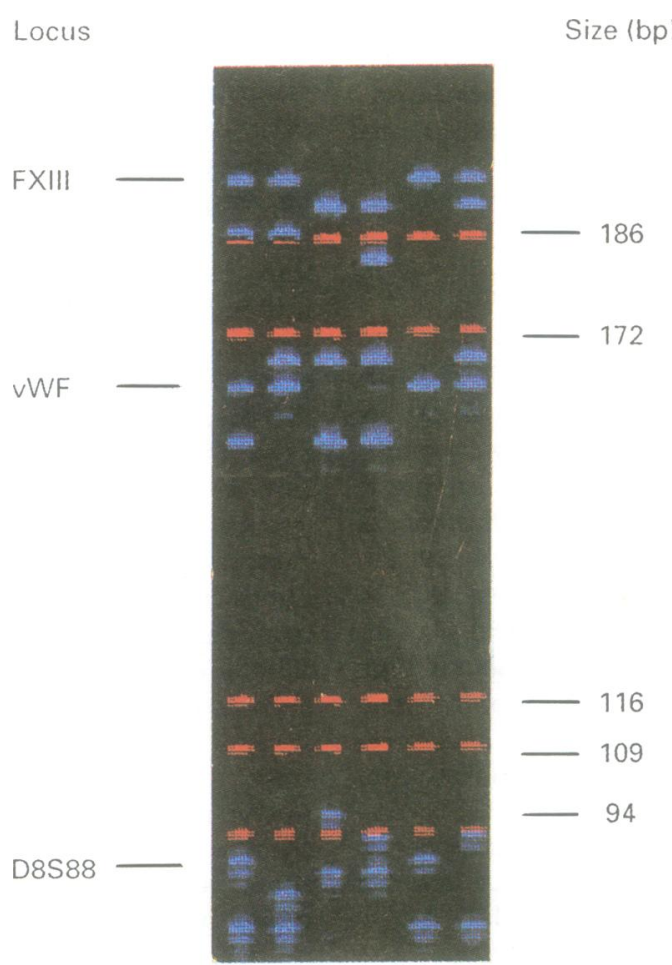

Figure 1 Gel image displaying multiplexed FAM-labelled FXIII, vWF, and D8S88 microsatellites. PCR products amplified from DNA extracted from amniotic fluid cell cultures and the corresponding maternal blood are shown in adjacent lanes for ease of comparison. The internal size standard is labelled with 6-carboxyrhodamine and appears red with the appropriate filter set. treatment as previously described. ${ }^{22}$ A small scale DNA extraction was performed on $300 \mu \mathrm{l}$ maternal blood following a similar method.

\section{MULTIPLEX PCR AMPLIFICATION}

The microsatellite loci used to screen for MCC are described in table 1 . Primers were synthesised and $5^{\prime}$ end labelled on an Applied Biosystems model 391 DNA synthesiser using either FAM or HEX phosphoramidites. The three triplex PCR reactions each contained $1.5 \mathrm{mmol} / 1 \mathrm{MgCl}_{2}, 200 \mathrm{mmol} / \mathrm{l} \mathrm{dNTPs}$, and $2 \%$ formamide. For D21S167, APOC2, and FXIII 8 pmol of each oligonucleotide primer was used, while for all other loci 5 pmol was found to be optimal. Following an initial denaturation at $94^{\circ} \mathrm{C}$ for five minutes, each multiplex reaction was amplified over 35 cycles of $94^{\circ} \mathrm{C}$ for one minute, $55^{\circ} \mathrm{C}$ for one minute, and $72^{\circ} \mathrm{C}$ for one minute followed by a final extension step at $72^{\circ} \mathrm{C}$ for five minutes.

FLUORESCENT PRODUCT DETECTION

Amplified PCR products were resolved on an Applied Biosystems 373A sequencer running Genescan 672 software as follows: $1 \mu 1$ PCR product was mixed with $2.5 \mu \mathrm{l}$ deionised formamide and added to $1.5 \mu$ loading buffer containing $4 \mathrm{fmol}$ of a Pst I digest of phage lambda DNA labelled with the fluorescent dye 6-carboxyrhodamine (ROX) (Applied Biosystems). The loading mix was then heated to $90^{\circ} \mathrm{C}$ for two minutes before loading on a $6 \%$ sequagel (National Diagnostics) polyacrylamide gel and electrophoresed at $1500 \mathrm{~V}$ for five to six hours. Allele sizes were determined automatically by the Genescan 672 software using the second order least squares method which produces a sizing curve based on multiple linear regression through the ROX labelled fragments of the internal standard for each lane.

\section{Results and discussion}

DNA extracted from 200 amniotic fluid cell cultures was initially screened against the corresponding maternal blood samples using the FXIII/vWF/D8S88 triplex PCR, as the tetranucleotide repeats were the simplest to score 


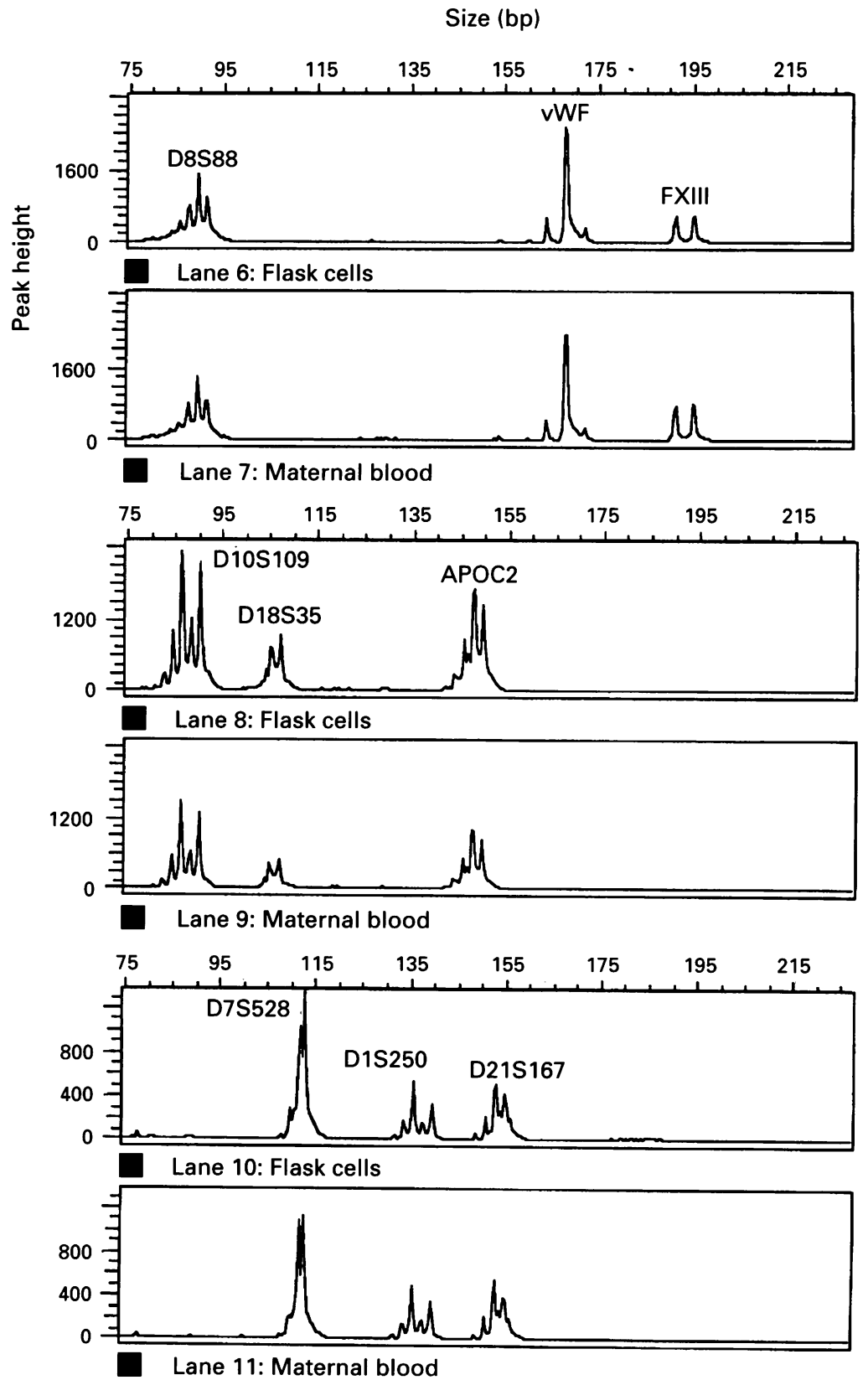

Figure 2 Electrophoretogram displaying the multilocus genotype generated from an amniotic fluid cell culture and the corresponding maternal blood. Identical genotypes at all
nine loci indicate maternal cell contamination.

(fig 1). Any instances where maternal cell contamination could not be ruled out were then screened using the two remaining triplex PCRs. In order to determine the sensitivity of the system, DNA samples were mixed at a series of known proportions. It was found that contamination at a level of $10 \%$ could be detected with certainty (data not shown) but lower levels tended to display little or no amplification. This is possibly because of competition between the two DNA species leading to preferential amplification of the more abundant DNA species. This effect limits the discriminatory power of this system, but nevertheless it remains extremely useful for the detection of MCC in the prenatal diagnosis of both chromosomal and genetic disorders.

The initial screening was sufficient to exclude MCC at a level greater than $10 \%$ in all but
Table 2 Alleles in common between the amniotic fluid cell cultures and the maternal blood for the probable case of MCC

\begin{tabular}{lccc}
\hline Locus & Alleles $(b p)$ & Frequency $^{*}$ & $p t$ \\
\hline FXIII & 190,194 & $0 \cdot 36,0 \cdot 35$ & $0 \cdot 355$ \\
vWF & 167,167 & $0 \cdot 42,0 \cdot 42$ & $0 \cdot 420$ \\
D8S88 & 87,89 & $0 \cdot 34,0 \cdot 21$ & $0 \cdot 275$ \\
D21S167 & 153,155 & $0 \cdot 07,0 \cdot 52$ & $0 \cdot 295$ \\
D1S250 & 136,140 & $0 \cdot 24,0 \cdot 18$ & $0 \cdot 210$ \\
D7S528 & 112,112 & $0 \cdot 31,0 \cdot 31$ & $0 \cdot 310$ \\
APOC2 & 147,149 & $0 \cdot 01,0 \cdot 23$ & $0 \cdot 120$ \\
D18S35 & 104,106 & $0 \cdot 40,0 \cdot 11$ & $0 \cdot 255$ \\
D10S109 & 86,90 & $0 \cdot 30.0 \cdot 15$ & $0 \cdot 225$
\end{tabular}

Multilocus probability $=5.4 \times 10^{-6}$

* Allele frequencies were estimated from 100 chromosomes of unrelated persons in the Northern Ireland population.

tProbability of mother and fetus having the same genotype at each locus.

one case. When this case was investigated using the two remaining triplex PCRs (D7S528/ D1S250/D21S167 and D10S109/D18S35/ APOC2), the DNA extracted from the flask cells and a further maternal blood sample again showed identical genotypes at all microsatellite loci (fig 2). Although paternal blood was unavailable, an estimate of the probability of mother and fetus having the same genotype at all nine loci can be obtained by considering the likelihood that the father has transmitted one or other of the shared alleles for each locus. This can be expressed as $(p+q) / 2$ for a single locus where $p$ and $q$ are the frequencies of the shared alleles. The multilocus probability is obtained as the product of the single locus probabilities (table 2). In this instance the likelihood that mother and fetus have the same genotype at all nine loci is calculated to be $5.4 \times 10^{-6}$, and the more probable explanation is that there was maternal cell contamination. This pregnancy was referred at 34 weeks' gestation with moderate ascites and hydrothorax, and a diagnosis of non-immune hydrops. The amniocentesis was unremarkable, with no obvious bloodstaining. Thus the circumstances of the amniocentesis is no indication of the presence of maternal cells and tests should be performed on any amniotic fluid cell culture where the karyotype is female and only one primary cell culture has been established. In no cases were three alleles observed in the amniotic fluid cell cultures indicating that MCC is probably a clonal event, that is, a small population of maternal cells undergoes clonal expansion to the extent that it almost becomes the exclusive cell population.

We now routinely check amniotic fluid cell cultures against the maternal blood when DNA testing for cystic fibrosis and other single gene disorders, and in all instances where the karyotype of the cultured cells is female and where cytogenetic analysis from two or more cultures is not possible.

1 Hamada $\mathrm{H}$, Kakunaga T. Potential Z-DNA forming sequences are highly dispersed in the human genome. Natur 1982;298:396-8.

2 Hamada H, Petrino MG, Kakunaga T. A novel repeated element with Z-DNA-forming potential is widely found in evolutionary diverse eukaryote genomes. Proc Natl Acad Sci USA 1982;79:6465-9.

3 Weber JL, May PE. Abundant class of human DNA polymorphisms which can be typed using the polymerase chain reaction. Am f Hum Genet 1989;44:388-96.

4 Litt M, Luty JA. A hypervariable microsatellite revealed by in vitro amplification of a dinucleotide repeat within the cardiac muscle actin gene. Am F Hum Genet 1989;44 $397-401$. 
5 Zuliani G, Hobbs HH. A high frequency of length polymorphisms in repeated sequences adjacent to Alu semorphisms in repeated sequences adjace

6 Beckmann JS, Weber JJ. Survey of human and rat microsatellites. Genomics 1992;12:627-31.

7 Edwards A, Civitello A, Hammond HH, Caskey CT. DNA typing and genetic mapping with trimeric and tetrameric

8 Mills KA, Buetow KH, Xu Y, et al. Genetic and physical maps of human chromosome 4 based on dinucleotide repeats. Genomics 1992;14:209-19.

9 Dracopoli NC, O'Connell P, Elsner TL, et al. The CEPH consortium linkage map of human chromosome 1. Genomics 1991;9:686-700

10 White RL, Lalouel JM, Nakamura V, et al. The CEPH consortium primary linkage map of human chromosome 10. Genomics 1990;6:393-412.

11 Trabetti E, Galavotti R, Pignatti P. Genetic variation in the Italian population at five tandem repeat loci amplified in vitro: use in paternity testing. Mol Cell Probes 1993; 7:81-7.

12 Wall WJ, Williamson R, Petrou M, Papaioannou D, Parkin populations. Hum Mol Genet 1993;2:1023-9.

13 Gill P, Ivanov PL, Kimpton C, et al. Identification of the remains of the Romanov family by DNA analysis. Nature Genet 1994;6:130-5.
14 Edwards AL, Hammond HA, Jin L, Caskey CT, Chakraborty $R$. Genetic variation at five trimeric and tetrameric tandem repeat loci in four human population groups.

15 Carrano AV, Lamerdin J, Ashworth LK, et al. A highresolution, fluorescence-based, semiautomated method for DNA fingerprinting. Genomics 1989;4:129-36.

16 Milunsky A. Genetic disorders of the fetus: diagnosis, prevention and treatment. New York: Plenum, 1979.

17 Benn PA, Hsu LYF. Maternal cell contamination of amniotic fluid cell cultures: results of a US nationwide survey. $A m$ f Med Genet 1983;15:297-305.

18 Benn PA, Schonhaut AG, Hsu LYF. A high incidence of maternal cell contamination of amniotic fluid cell cultures. Am $\mathcal{F}$ Med Genet 1983;14:361-5.

19 Bui TH, Iselius L, Lindsten J. European collaborative study on prenatal diagnosis: mosaicism, pseudomosaicism and single abnormal cell in amniotic fluid cell cultures. Prenat Diagn (special issue) 1984;4:145.

20 Worton RG, Stern R. A Canadian collaborative study of mosaicism in amniotic fluid cell cultures. Prenat Diagn (special issue) 1984;4:145.

21 Rooney DE, Czepulkowski BH. Tissue culture methods in human cytogenetics. In: Human cytogenetics: a practical approach. Oxford: IRL Press, 1986:1-36.

22 Jeanpierre $M$. A rapid method for the purification of DNA from blood. Nucleic Acids Res 1987;15:9611. 